\title{
Fear of crime determinants. Empirical case study of Poland
}

Keywords: fear of crime, victimization, regression models, criminal policy, criminology

\begin{abstract}
The study explains the nature and strength of the influence of the determinants of fear of crime. According to other studies gender, age, education, place of residence, material status, worldview and religious orientation, victimization influence the level of fear of crime. In order to verify the impact of these factors, the CATREG analysis technique was used. Variables such as the level of anomie, crime, unemployment and suicide rates were introduced, as an original author's concept. A model of factors influencing fear of crime was created. The most important element of it turned out to be prior victimization, as well as - to a lesser extent - negative attitudes towards state institutions that are to ensure safety and the occupation.
\end{abstract}

\section{Introduction}

The interest in fear of crime in social communities in academic terms first appeared in the late 1960s and became one of the most studied topics in contemporary criminology. It is an interdisciplinary issue, and much attention is paid to it not only in criminology, but also, for example, in social ecology, social psychology and geography ${ }^{1}$. Nearly six

* ORCID ID: https://orcid.org/0000-0003-2223-5997; assistant professor at the Faculty of Political Science and International Studies at the University of Warsaw. Email: d.mider@ uw.edu.pl.

1 B. Doran, M. Burgess, Putting Fear of Crime on the Map. Investigating Perceptions of Crime Using Geographic Information Systems, New York 2012. 
decades in Western criminology have led to a diversified understanding of the concept of fear of victimization of oneself or one's family and friends ${ }^{2}$. It is worth highlighting some of the most important and newest studies on fear of crime in the Polish scientific literature. The current Polish achievements include valuable research conducted by the Institute of Justice ${ }^{3}$ with particular emphasis on the subsequent volumes of the Atlas of Crime in Poland, published on the basis of research conducted since $1992^{4}$. The numerous measurements taken by the Public Opinion Research Center (Centrum Badań Opinii Społecznej) and the Police Headquarters (Komenda Główna Policji) should be mentioned.

In English criminology, this concept is known as fear of crime 5 or less often sense of security ${ }^{6}$. In general, the fear of crime construct is defined narrowly, that is, in emotional terms ${ }^{7}$. Jodie Lane and her research team summarize the discussion on the definition issues, demonstrating, on the basis of definitions present in the literature on the subject, three constitutive features of fear of crime: I. an emotional response, II. to a danger or threat, III. of an actual or potential criminal incident ${ }^{8}$.

During the analysis of the literature on the subject, the following research question was formulated: Whether and to what extent sociodemographic factors (age, sex, education, income, location and magnitude of the place of residence, marital status and family situation, unemployment rate, crime rate and crime detection rate) and psychographic factors (prior victimization, political and religious attitudes/beliefs, the judgment of state institutions ensuring security, attitudes towards values related to the state and the law) differentiate intensity of the fear of crime. This research problem results in a non-directional hypothesis:

2 J. Jackson, Fear of Crime: An Entry to the Encyclopedia of Theoretical Criminology, [in:] M. Miller (eds.), Encyclopedia of Theoretical Criminology, 2014, in print.

3 P. Ostaszewski, Nasilenie i determinanty lęku przed przestępczościa, Warsaw 2012; P. Ostaszewski, Lęk przed przestępczościq. Aspekty teoretyczne, metodologiczne i empiryczne, Warsaw 2014.

4 B. Gruszczyńska, M. Marczewski, A. Siemaszko, Atlas przestępczości w Polsce 5, Warsaw 2015.

5 C. Hale, Fear of Crime: A Review of the Literature, «International Review of Victimology» 1996, no. 4 (2), pp. 79-150.

6 M. Szatan, Strach a lęk w ujęciu nauk humanistycznych, «Studia Gdańskie» 2012, no. 31, pp. 325-342; W. G. Skogan, The various meanings of fear, [in:] The Fear of Crime and Criminal Victimization, Stuttgart 1993.

7 K. F. Ferraro, R. LaGrange, The Measurement of Fear of Crime, «Sociological Inquiry» 1987, no. 57 (1), pp. 70-97; R.A. Sundeen, J. T. Mathieu, The Fear of Crime and Its Consequences Among Elderly in Three Urban Communities, «The Gerontologist» 1976, no. 16 (3), pp. 211-219; J. Garofalo, The Fear of Crime: Causes and Consequences, «Journal of Criminal Law and Criminology» 1981, no. 72 (2), pp. 839-857.

8 J. Lane, et al., Fear of Crime in the United States: Causes, Consequences, and Contradictions, Durham 2014. 
social, demographic and attitudinal differentiation result in a different level of fear of crime. This hypothesis also has a comparative value - to what extent Polish society fits into Western trends in the scope of determinants of fear of crime. In this study, we try to determine the combined impact of social, demographic and psychographic variables in line with newer studies, both Polish and foreign, in the field of fear of crime, using multi-dimensional modeling and other aggregated, synthetic measures ${ }^{9}$.

\section{Materials and Methods}

The basis of this paper is a study conducted on a statistically representative sample of $\mathrm{N}=1000$ adult Poles $(18+$ y.o. $)$. The study was financed by Justice Fund administered by the Minister of Justice. The study was carried out by the University of Warsaw Political Science Graduates Association and the Centre Marketing Research Indicator. The study was carried out from November 1 to 10, 2020 using computer-assisted telephone interviews ${ }^{10}$. In the methodological aspect we note higher availability of respondents than in other techniques (e.g. classical face-to-face questionnaire surveys). In terms of psychological-interaction aspect, we notice a clearly greater comfort of interaction between the interviewer and the respondent. Taking into account the technical-organizational aspect, a significant feature of telephone surveys is the high degree of control over the research process. Research tools (questionnaires) can be constructed as more complex and multidimensional in CATI technique. Research software enables rapid data collection and processing, which significantly reduces the duration of the entire research project. Computer support and telephone contact are also factors that significantly reduce the financial and organizational cash outlays necessary to conduct the survey. As

9 T. Franklin, C. Franklin, N. Fearn, A multilevel analysis of the vulnerability, disorder, and social integration models of fear of crime, «Social Justice Research» 2008, no. 21, pp. 204-227; B. Gruszczyńska, M. Marczewski, A. Siemaszko, Atlas przestępczości w Polsce 4, Warsaw 2009; P. Ostaszewski, Nasilenie i determinanty lęku przed przestępczościa, Warsaw 2012; B. Robinson et al., Multilevel longitudinal impacts of incivilities: Fear of crime, expected safety, and block satisfaction, «Journal of Quantitative Criminology» 2003, no. 19, pp. 237-274; B. Scarborough et al., Assessing the relationship between individual characteristics, neighborhood context, and fear of crime, «Journal of Criminal Justice» 2010, no. 38, pp. 819-826; B. Wyant, Multi-level impacts of perceived incivilities and perceptions of crime risk on fear of crime, «Journal of Research in Crime and Delinquency» 2008, no. 45, pp. 39-64.

10 The research of Poles is conducted on a monthly basis. In the context of the lockdown, no increase or decrease in the fears of Poles was found. 
a result of the above-mentioned advantages of CATI we obtain a higher percentage of respondents agreeing to participate in the survey compared to other research methods (higher response rate). Moreover, these elements translate into a much higher quality of data: precision, accuracy, low error rate, reliability, relevance. Most importantly, computer-assisted telephone surveys have the ability to generalize sample results to a higher population than other available research methods ${ }^{11}$.

The condition of ensuring representativeness is the appropriate sampling frame, ie the list of elements of the general population. In the case of telephone surveys, there is an almost perfect availability of the sampling frame, in contrast to other quantitative survey methods ${ }^{12}$. Telephony is of a mass nature: according to the report of the Office of Electronic Communications and CBM Indicator, 92\% of mobile phones are used and landline phones function in $24 \%$ households ${ }^{13}$. The study used a sample selection developed in the US quantitative research methodology by Warren Mitofsky \& Joseph Wakesberg called Random Digit Dialing (RDD) ${ }^{14}$. It is recognized by researchers dealing with computer-assisted telephone research as an optimal and classical technique ${ }^{15}$. This technique was updated in research practice ${ }^{16}$, also taking into account the impact of the dynamic development of mobile telephony on the practice and

11 In connection with the disturbing fashion for computer assisted web interviews (CAWI) research, it is worth pointing out why this research technique was definitely excluded. The most serious and widely discussed allegation relating to the CAWI research concerns the unavailability of the full frame of internet user sampling. There is talk of the lack of representativeness of this type of research and the impossibility of drawing conclusions from the studied sample to the population. This objection can be formulated more definitely: where there is no full or almost full sampling frame (i.e. the set that will be used to select the sample), there is no quantitative research. Researchers try to solve this problem in various ways by using, inter alia, panel research, which, however, does not solve the problem of representativeness. The second premise is the complexity of the survey and the need to explain to the interviewee and assess whether the respondent understood the issues. Hence the need to assist an interviewer as an intermediary in communication.

12 D. Mider, Ewaluacja wybranych metod badan społecznych $w$ Internecie, [in:] D. Mider, A. Maksimowicz (eds.), Cyberpolitologia. Badanie polityki w Internecie, ACAD, Warsaw 2013, pp. 57-95.

13 PBS, UKE, Indicator, Rynek ustug telekomunikacyjnych $w$ Polsce $w 2015$ roku. Raport z badania klientów indywidualnych, December 2015, p. 11.

14 W. Mitofsky, Sampling of telephone household, unpublished Central Bureau of Statistics memorandum, 1970 unnumbered pages; J. Waksberg, Sampling Methods for Random Digit Dialing, «Journal of the American Statistical Association» 1978, no. 73, pp. 40-46.

15 R.F. Potthoff, Some generalisation of the Mitofsky-Waksberg technique for Random Digit Dialing, «Journal of the American Statistical Association», 1987, no. 82, pp. 409-418.

16 C. Tucker, R. Casady, J. Lepkowski, Sample Allocation For Stratified Telephone Sample Designs, Proceedings of the Survey Research Methods Sections, American Statistical Association, Alexandria 1992, pp. 566-571. 
standards of sampling ${ }^{17}$. It allows for the random selection of the sampling frame and, as a result, for obtaining representativeness in terms of socio-demographic features crucial for the research purposes, such as: gender, age, education, place and size of residence, occupation, income. In practice, it consists in selecting telephone numbers from telephone numbering tables, and then generating random telephone numbers within the selected layer (which is the area numbering code). The next step is the elimination of non-functioning telephone numbers with the use of special validation software, and then an adequate determination, using a series of questions, of the probability of a specific respondent being in the database (due to the number of telephone numbers they have). Such a procedure minimizes the sample bias (cumulative error of omission, inclusion, repetition, possibility), and compares favorably with other probabilistic sampling techniques. In analyzes, a set of measures was used. Inductive statistics encompasses Pearson's chi-square covariation $\left(\chi^{2}\right)$ and its derivatives, V Cramér's contingency coefficient, eta $(\eta)$ coefficient, Pearson's R and Spearman's rho $(\rho)$ correlation. As a quantitative analysis technique, descriptive statistics were also used, often based on one- and two-dimensional tables as well as on measures of central tendency and dispersion. In order to measure the cumulative impact of variables, Categorical Regression (CATREG) / Optimal Scaling was used. Optimal Scalling regression (OS-regression), formerly (and still) known as Categorical Regression (CATREG), comes from psychometry, where nonlinear data analysis using the optimal scaling methodology has been studied quite extensively. The development and synthesis works of Albert Gifi's group operating at the University of Leiden are the key contribution ${ }^{18}$. The source of this method is correspondence analysis ${ }^{19}$ and multidimensional scalling $(M D S)^{20}$. The

17 J. M. Brick and others, Cell phone survey feasibility in the U.S.: Sampling and calling cell numbers versus landline numbers, «Public Opinion Quarterly» 2007, no. 71, pp. 23-39; J. M. Brick and others, Nonresponse bias in a dual frame sample of cell and landline numbers, "Public Opinion Quarterly» 2006, no. 70, pp. 780-793; C. Kennedy, Evaluating the effects of screening for telephone service in dual frame RDD surveys, «Public Opinion Quarterly» 2007, no. 71, pp. 750-771; S. Keeter and others, Costs and benefits of full dual frame telephone survey designs, Paper presented at the $63^{\text {rd }}$ Annual Conference of the American Association for Public Opinion Research, New Orlean 2008.

18 A. Gifi, Nonlinear multivariate analysis, Wiley series in probability and mathematical statistics, Chichester 1990.

19 M. J. Greenacre, Theory and Applications of Correspondence Analysis, London 1984.

20 R. N. Shepard, The analysis of proximities: Multidimensional scaling with an unknown distance function. I, «Psychometrika» 1962, no. 27, pp. 125-140; J. B. Kruskal, Multidimensional scaling by optimizing goodness of fit to a nonmetric hypothesis, «Psychometrika» 1964, no. 29, pp. 1-28; 
central concept of this method is nonlinear regression with categorical variables by optimally scaling categories in categorical data.

\section{Results}

Based on the collected empirical data, a statistical analysis was performed with the use of descriptive and inductive measures. The limited volume of the text made it possible to present only the key results. The results of the inductive statistics are listed below, and the descriptive statistics are included in the Discussion and Conclusions section. Table 1 shows the variables whose correlation with fear of crime turned out to be statically significant, although not very strong, but in social sciences such results are considered satisfactory. Among the tested single variables, the following turned out to be significant: gender and the respondent's place of residence. Moderately important are: attitude towards religion, income - self-esteem, marital status, income - household (amount for all household members). The size of the place of residence and the level of education are variables that turned out to be negative, but to a small extent. This means that the larger the place of residence in terms of population, and the higher the education, the greater the fear of crime. The results can be generalized from sample to population. The table lists all the variables that turned out to be statistically significant; the results are listed in order from most important to least important.

Construction of the model of the joint interaction of variables using the CATREG method. The hypothesis of the combined effect of features, referred to as interaction in the statistical literature on the subject, was verified. For this purpose, a regression model for categorical regression (CATREG) was built. The model was made using the so-called top-down method which turned out to be more satisfactory than the bottom-up method. The top-down method consists in incorporating all potentially important factors into the model (relevant from the point of view of literature or intuition and the researcher's predictions), and then gradual, systematic elimination of the variables showing the lowest level of tolerance. The tolerance level is assessed on the basis of the goodness of fit expressed by the F statistic.

L. Guttman, A general nonmetric technique for finding the smallest coordinate space for a configuration of points, «Psychometrika»1968, no. 33, pp. 469-506. 
Table 1. Fear of crime - differentiation in terms of sociographic, demographic and psychographic characteristics $(\mathrm{N}=1002$, weighted data)

\begin{tabular}{|c|c|}
\hline Variables* & $\begin{array}{l}\text { Correlation } \\
\text { coefficients } \\
\text { between variables } \\
\text { (within the range } \\
\text { of a given variable) }\end{array}$ \\
\hline Voividship (16 categories) & $\begin{array}{c}\chi^{2}=63,088 ; \mathrm{p} \leq 0,05 \\
\mathrm{~V}=0,151 ; \mathrm{p} \leq 0,05 \\
\eta=0,094\end{array}$ \\
\hline Gender (2 categories) & $\begin{array}{c}\chi^{2}=22,582 ; p \leq 0,001 \\
V=0,151 ; p \leq 0,001 \\
\eta=0,136\end{array}$ \\
\hline $\begin{array}{l}\text { Attitude towards religion ( } 5 \text { categories: Non-believers, Having } \\
\text { doubts about matters of faith, Believers and non-practitioners, } \\
\text { Believers and practitioners, Don't know) }\end{array}$ & $\begin{array}{c}\chi^{2}=33,996 ; p \leq 0,05 \\
V=0,105 ; p \leq 0,05 \\
\eta=0,134\end{array}$ \\
\hline $\begin{array}{l}\text { Income - self-esteem ( } 6 \text { categories: It is enough for everything } \\
\text { and we save for the future, It is enough for everything without special } \\
\text { sacrifices, but we do not save for the future, We live sparingly and } \\
\text { thanks to that it is enough for everything, We live very sparingly to } \\
\text { save for more serious purchases, Money is enough only for basic needs, } \\
\text { Money is not enough even for the cheapest food) }\end{array}$ & $\begin{array}{c}\chi^{2}=21,356 ; p \leq 0,001 \\
V=0,103 ; p \leq 0,05 \\
\eta=0,149\end{array}$ \\
\hline $\begin{array}{l}\text { Martial status ( } 6 \text { categories: single / unmarried, married, in } \\
\text { relationship - cohabiting / non-cohabiting, divorced, widower / } \\
\text { widow) }\end{array}$ & $\begin{array}{c}\chi^{2}=34,0,19 ; p \leq 0,05 \\
V=0,102 ; p \leq 0,05 \\
\eta=0,105\end{array}$ \\
\hline $\begin{array}{l}\text { Income - household (amount for all household members, } \\
\text { interval scale, } 7 \text { categories: below } 1000 \text { PLN, 1000-1500 PLN, } \\
\text { 1501-2000 PLN, 2001-3000 PLN, 3001-5000 PLN, } \\
\text { 5001-10 000 PLN, above } 10000 \text { PLN) }\end{array}$ & $\begin{aligned} \rho= & 0,058 ; p \leq 0,1 \\
& \eta=0,067\end{aligned}$ \\
\hline $\begin{array}{l}\text { Size of the place of residence ( } 8 \text { categories: village colony, } \\
\text { village, village near the city, city with less than } 20,000 \text { residents, } \\
\text { city } 20,000-50,000 \text { residents, city } 50,000-100,000 \text {, } \\
\text { city } 100,000-500,000 \text {, city above than } 500,000 \text { residents) }\end{array}$ & $\begin{array}{c}\rho=-0,053 ; p \leq 0,1 \\
\eta=0,061\end{array}$ \\
\hline $\begin{array}{l}\text { Education ( } 3 \text { categories: primary education, secondary } \\
\text { education, higher education) }\end{array}$ & $\begin{array}{c}\rho=-0,074 ; p \leq 0,05 \\
\eta=0,097\end{array}$ \\
\hline
\end{tabular}

* The survey questionnaire and the database are available at the research project administrators: https://badaniadlabezpieczenstwa.pl/pomiar-zjawiska-przestepczosci-na-potrzeby-dzialan-edukacyjnych-i-profilaktycznych-listopad-2020/ (20.07.2021). The sociodemographic variables that have become the basis of the model are asked in a standardized way, therefore their full content is not presented.

Source: author's own study. 
The following independent variables were taken for the calculations: sex of the respondent, age, education, type of residence, voivodship, number of people in the household, marital status, monthly net household income, the way of managing income in the household, attitude towards religion, political self-identification, occupation, average amount of time spent on the Internet per week, measures to protect yourself in the event of an emergency on a daily basis, victimization, indicator of anomy (attitudes to unfair law), attitudes to law enforcement, suicide, unemployment, crime rate 21 .

The dependent variable of the model was the synthetic indicator of fear of crime created using the arithmetic mean of the following 19 variables: homicide, attempted homicide, beatings, robbery, detention, kidnapping, punishable threats, stalking, rape / attempted rape or forced sexual activity, verbal sexual harassment, abuse of dependence (in the workplace) in order to lead to sexual activity, offending religious feelings, religious discrimination, discrimination on the basis of features and / or beliefs, violation of bodily integrity, defamation, insult, physical or mental abuse, accident, theft, fraud, burglary, data phishing, including identity theft, disclosure of private / professional data, terrorist attack.

The boundary conditions regarding the number of variables (the minimum number of units of analysis per predictor) were met -28 dependent variables require a minimum of 280 analyzed cases, and optimally 560 . There was no co-variation between the key variables constituting the model (Pearson's $\mathrm{R}$ correlation coefficient did not exceed in any in the case of negligible values), and also - which is an indicator of the lack of covariance of the values of the tolerance coefficient close to one for all variables in the model. The calculation results for the top-down optimal scaling are presented in tables 2, 3 and 4 .

Table 2. Model summary for top-down categorical regression

\begin{tabular}{|l|c|}
\hline Multiple R & 0,560 \\
\hline R square & 0,314 \\
\hline Adjusted R square & 0,266 \\
\hline
\end{tabular}

Source: Own analysis based on the results of the quantitative survey.

21 The variables are standardized / universal adopted, among others, in CBOS research, the full text of the questionnaire is available from the administrators of the study and the author of the article: https://badaniadlabezpieczenstwa.pl/pomiar-zjawiska-przestepczosci-na-potrzeby-dzialan-edukacyjnych-i-profilaktycznych-listopad-2020/ (20.07.2021). 
Fear of crime determinants. Empirical case study of Poland

Table 3. Analysis of variance (ANOVA) for the top-down categorical regression

\begin{tabular}{|l|c|c|c|c|c|}
\cline { 2 - 6 } \multicolumn{1}{c|}{} & Sum of squares & $\begin{array}{c}\text { Degrees of freedom } \\
(\mathbf{d f})\end{array}$ & Mean square & F & Significance \\
\hline Regression & 306,020 & 64 & 4,782 & 6,498 & $\mathrm{p} \leq 0,01$ \\
\hline Residues & 668,905 & 909 & 0,736 & & \\
\hline Total & 974,925 & 973 & & & \\
\hline
\end{tabular}

Source: Own analysis based on the results of the quantitative survey.

Table 4. Categorical regression top-down model (CATREG)

\begin{tabular}{|c|c|c|c|c|c|c|c|c|c|c|}
\hline 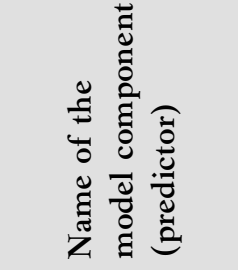 & 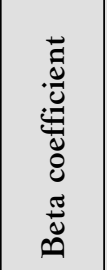 & 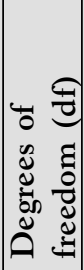 & I工 & 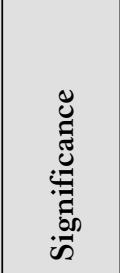 & 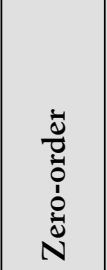 & 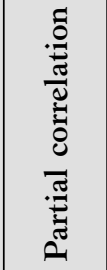 & 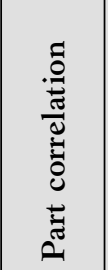 & 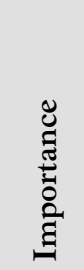 & 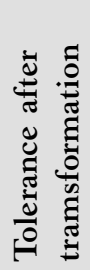 & 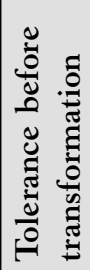 \\
\hline Victimization & 0,382 & 8 & 74,676 & $\mathrm{p} \leq 0,01$ & 0,416 & 0,409 & 0,371 & 0,506 & 0,943 & 0,908 \\
\hline $\begin{array}{l}\text { Indicator of } \\
\text { institutional } \\
\text { correlates of } \\
\text { fear of crime }\end{array}$ & $-0,164$ & 8 & 11,390 & $\mathrm{p} \leq 0,01$ & $-0,256$ & $-0,186$ & $-0,157$ & 0,134 & 0,911 & 0,947 \\
\hline Profession & 0,171 & 14 & 28,057 & $\mathrm{p} \leq 0,01$ & 0,207 & 0,196 & 0,166 & 0,113 & 0,945 & 0,881 \\
\hline $\begin{array}{l}\text { Attitude } \\
\text { towards religion }\end{array}$ & 0,096 & 4 & 9,136 & $\mathrm{p} \leq 0,01$ & 0,203 & 0,109 & 0,091 & 0,062 & 0,885 & 0,896 \\
\hline $\begin{array}{l}\text { Political self- } \\
\text {-identification }\end{array}$ & 0,088 & 7 & 9,242 & $\mathrm{p} \leq 0,01$ & 0,212 & 0,098 & 0,081 & 0,059 & 0,857 & 0,953 \\
\hline $\begin{array}{l}\text { Place of } \\
\text { residence } \\
\text { (voividship) }\end{array}$ & 0,129 & 15 & 21,028 & $\mathrm{p} \leq 0,01$ & 0,116 & 0,153 & 0,128 & 0,048 & 0,995 & 0,995 \\
\hline Sex & 0,133 & 1 & 15,919 & $\mathrm{p} \leq 0,01$ & 0,099 & 0,155 & 0,130 & 0,042 & 0,957 & 0,946 \\
\hline $\begin{array}{l}\text { Age of the } \\
\text { respondent }\end{array}$ & $-0,084$ & 2 & 4,155 & $\mathrm{p} \leq 0,05$ & $-0,133$ & $-0,096$ & $-0,080$ & 0,036 & 0,896 & 0,802 \\
\hline Marital status & 0,063 & 5 & 4,261 & $\mathrm{p} \leq 0,01$ & 0,004 & 0,073 & 0,061 & 0,001 & 0,934 & 0,850 \\
\hline
\end{tabular}

Source: Own analysis based on the results of the quantitative survey. 
The fit of the optimal scaling model expressed with multiple $\mathrm{R}$ was 0.56 , which is considered a moderate (significant) relationship. The total variability of the dependent variable explained by the total influence of independent variables was 0.314 (so the model explains $31.4 \%$ of the variability of the crime fear factor). The moderate number of factors in the model (9) slightly lowers the coefficient, still leaving it substantial to 0.266 (26.6\%). However, the model is statistically significant at probability value greater than one percent. The visual evaluation of the sum of squares for regression and residuals in ANOVA (table 3) shows that the regression model explains nearly one half of the variability which prompts its behavior and presentation. Fear of crime is best explained by the following system of variables that make up the interactive model (non-accidental order - from the most important factor): cumulative averaged victimization rate, occupation, gender of the respondent, place of residence (voividship), attitude towards religion, political self-identification, marital status, age of the respondent (broken down into three categories - young, middle and older generations) and indicator of institutional correlates of fear of crime (attitudes towards police, municipal guard, judiciary, judiciary in criminal cases, the public prosecutor's office, the parliament, only in the area of creating criminal law and the army).

The most frequently represented factors of the model are sociodemographic (five variables: gender, age, place of residence, marital status and occupation), three variables representing attitudes (towards state institutions, religion and the sphere of politics) and the fact of being a victim of crime in the past. This exhausts the classic components most often mentioned in the literature on the subject. Prior victimization is the most important factor in the model - it accounts for more than half of the "predictive power" of the model (validity was 50.6\%). It distances all other values. The next two components of the model are negative attitudes towards state institutions which are to ensure security (the share in the entire model, i.e. the importance factor amounted to 13.4\%) and the occupation (11.3\%). The other components of the model play a much smaller role, the value of each of them is below $10 \%$. These are attitudes towards religion, political self-identification, voivodship as a place of residence, gender, age and marital status. Importantly, the place of residence turned out to be significant, in contrast to the crime rate, also tested by voivodship. It is worth noting that two factors are destimulants of the model (negative value of the $\beta$ coefficient). These are the attitudes towards the state institutions and the age of the respon- 
dent. The lower the trust in state institutions, the greater the fear of crime. Similarly - the lower the age, the greater the fears (slight regularity). The last of the variables: marital status has a slight impact on the model, but it was left in the model due to its significance $(\mathrm{p} \leq 0.01)$.

\section{Discussion and Conclusion}

The following considerations attempt to explain the obtained model and compare the obtained results with the results of similar studies from other countries where such studies are more common.

Prior victimization, i.e. the fact that the respondent has been a victim of a crime, has the strongest influence on fear of crime. This trauma explains slightly more than half of the variance $(50.6 \%)$ of the fear of crime dependent variable. It is the strongest variable in the model and it outlasts all the others ${ }^{22}$.

There is a widespread belief in the literature that victimization increases the probability of increasing the fear of crime ${ }^{23}$. However, it is equally common to believe that being a victim of crime does not fully explain the generalized fear of crime ${ }^{24}$. Other researchers find no or only slight connections between victimization and fear of crime ${ }^{25}$. It must therefore be presumed that there is a gap between crime and fear of crime, even with the crime rate statistics falling ${ }^{26}$. The above observations lead to an in-depth analysis of groups representing signifi-

22 The results of the study from the CBOS Research Communication 67/2021 are only apparently similar. First, in this study, the relationship between victimization and fear of crime was investigated subjectively on the basis of respondents' declarations. In the study described in this article, it is examined intersubjectively - using the regression method. This is an important observation: although the respondents indicate that being a victim of crime does not affect their fear of crime, it is not true - victimization increases their fear (unconsciously). Second, the CBOS study asked about victimization in the last five years, and the study asked about victimization throughout life. Thirdly - for the sake of order - the selection of the sample in the CBOS survey was different: representativeness can be judged on the basis of researchers' declarations, not statistical rules.

23 C. Hale, P. Pack, J. Salked, The structural determinants of fear of crime: an analysis using census and crime survey data from England and Wales, «International Review of Victimology» 1994, no. 3, pp. 211-233.

24 W. G. Skogan, M. G. Maxfield, Coping with crime: individual and neighborhood reactions, Thousand Oaks 1981.

25 A. Tseloni, C. Zarafonitou, Fear of Crime and Victimisation: A Multivariate Multilevel Analysis of Competing Measurements, «European Journal of Criminology» 2008, no. 5, pp. 387-409.

26 W. G. Skogan, The impact of victimization on fear, «Crime Delinquency» 1987, no. 33, pp. 135-154. 
cantly higher levels of fear of crime for both cognitive and preventive purposes. The conducted research shows that Poles from among crimes as much as 31.7 percent. Poles have fallen victim to theft or misappropriation throughout their lives. Frauds (15.7\%), burglaries (15.2\%), beatings (15.0\%) are also frequent. Women are a particularly vulnerable group to physical or psychological abuse, verbal sexual harassment, and rape and attempted rape. Male victimization more often concerns such crimes as theft and misappropriation, beatings and fraud. Young people are more often exposed to defamation and violations of physical integrity, because age is a negative correlate of the experience of these types of crimes. In turn, the middle generation of Poles (35-65 y.o.) more often than other age groups are victims of theft or misappropriation and disturbing of domestic peace. On the other hand, education positively correlating to crimes such as theft or misappropriation, fraud, burglary, defamation and insult, violation of bodily integrity, punishable threats, harassment, stalking, disturbing domestic peace, beating. Thus, various social groups emerge that require different protection due to the diverse spectrum of crimes affecting them. In Poland, victimization turns out to be a key factor, so fear of crime is related to past trauma. Studying the relationship between these variables is crucial - the effects of victimization are severe and long-lasting. They include physical, mental and behavioral consequences and significantly affect the quality of life of victims of victimization ${ }^{27}$.

Attitudes towards state institutions and the profession have a moderate impact on fear of crime. Together, this factors explain about a quarter (24.7\%) of the variance of the dependent variable. Institutional correlates included an assessment of the impact on the level of the sense of security of institutions like: parliament, police and other services, $\operatorname{courts}^{28}$. Empirical evidence from other studies suggest to some extent

27 M. Warr, Fear of crime in the United States: Avenues for research and policy, «Criminal Justice» 2000, no. 4, pp. 451-489.

28 A positive relationship sees: H. D. Lee, B. W. Reyns, D. Kim, Fear of Crime Out West: Determinants of Fear of Property and Violent Crime in Five States, "International Journal of Offender Therapy and Comparative Criminology» 2020, no. 64 (12), pp. 1299-1316; G. Meško et al., Police Efforts in the Reduction of Fear of Crime in Local Communities - Big Expectations and Questionable Effects, «Sociologija. Mintis ir veiksmas» 2007, no. 2 (20), pp. 70-91; J. Jackson et al., Does the Fear of Crime Erode Public Confidence in Policing?, «Policing» 2009, no. 3 (1), pp. 100-111; E. Alda, R. Bennett, M. Morabito, Confidence in the police and the fear of crime in the developing world, «Policing An International Journal of Police Strategies and Management» 2017, no. 40 (2), pp. 366-379; J. Abbott, S. A. McGrath, D. C. May, The Effects of Police Effort on Victims' Fear of Crime, «American Journal of Criminal Justice» 2020, no. 45, pp. 880-898. 
that sense of security is correlated with the perception of the integrity of the judiciary, trust in the prevention and prosecution authorities, and general trust in the justice system ${ }^{29}$. However, the results of empirical research in this area remain inconclusive - other researchers, however, do not find such evidence or present the opposite ${ }^{30}$. In the case of Poles, the lower the trust in the above-mentioned institutions, the greater the sense of threat. The relationship between profession and fear of crime is a local Polish phenomenon. Other researchers take up this issue rarely, and the type of profession is not an important factor in their models ${ }^{31}$. The weakest groups experiencing the highest fear of crime. They are: unregistered / registered unemployed persons (25\% / 23\% of them feels fear of crime). retired pensioners (22\%), office workers $(22.5 \%)$, and operators, machine and device fitters (22\%). The lowest fear of crime is demonstrated by industrial workers and craftsmen (3.6\%), farmers, gardeners, foresters or fishermen (6\%).

The remaining six variables are of marginal importance. Together, they explain the remaining quarter of the variance of the dependent variable. Taking into account features such as gender (women with higher fear of crime), age (to some extent) and prior victimization, Poland society does not differ from the findings of Western societies. However, the similarities end there. The strong correlation with fear of crime factors such as the political worldview (leftists) and religious beliefs (doubtful and unbelievers), education (higher), marital status (in a relationship), age (middle-aged) are atypical.

Most Central European and Southern European reports fear of crime at approximately $20 \%$ an above in the adult population ${ }^{32}$. Among Poles

29 More on this topic: A. J. Singer et al., Victimization, Fear of Crime, and Trust in Criminal Justice Institutions: A Cross-National Analysis, «Crime \& Deliquency» 2019, no. 65 (6), pp. 822-844; M. T. Costelloe, T. Chiricos, M. Gertz, Exploring the relevance of crime salience and economic insecurity, «Punishment \& Society» 2009, no. 11, pp. 25-49; M. J. Hogan, T. Chiricos, M. Gertz, Economic insecurity, blame, and punitive attitudes, «Justice Quarterly» 2005, no. 22, pp. 392-412.

30 More on this topic: S. E. Barkan, S. F. Cohn, Racial prejudice and support for the death penalty by whites, «Journal of Research in Crime \& Delinquency» 1994, no. 31, pp. 202-209; A. King, S. Maruna, Is a conservative just a liberal who has been mugged? Exploring the origins of punitive views, «Punishment \& Society» 2009, no. 11, pp. 147-169.

31 G. Macassa and other, Fear of crime and its relationship to self-reported health and stress among men, «Journal of Public Health Research» 2017, no. 6 (3), pp. 169-174.

32 Compare: A. Vieno, M. Roccato, S. Russo, Is fear of crime mainly social and economic insecurity in disguise? A multilevel multinational analysis, «Journal of Community \& Applied Social Psychology» 2013, no. 23, pp. 519-535; M. Visser, M. Scholte, P. Scheepers, Fear of crime and feelings of unsafety in European countries: Macro and micro explanations in cross-national perspectives, «The Sociological Quarterly» 2013, no. 54, pp. 278-301. 
it is only $16.8 \%$. So compared to other European countries, Polish society feels relatively safe. Poland with these results comes close to the lowest rates of fear that are reported in the Nordic countries and a few Central European countries (Austria, the Netherlands, and Switzerland), where approximately $10 \%$ to $20 \%$ of the population feels fear of crime $e^{33}$. However, the conducted study managed to distinguish groups that felt threatened to a greater extent than others. It is particularly important that these groups are characterized by a greater degree of vulnerability than others due to their characteristics. This leads to a request to look for comprehensive solutions due to the devastating mental, physical and social effects of fear of crime.

\section{Bibliography}

Abbott J., McGrath S. A., May D. C., The effects of Police Effort on Victims' Fear of Crime, «American Journal of Criminal Justice» 2020, no. 45.

Alda E., Bennet R., Morabito M., Confidence in the police and the fear of crime in the developing world, «Policing An International Journal of Police Strategies and Management» 2017, no. 40 (2).

Barkan S. E., Cohn S. F., Racial prejudice and support for the death penalty by whites, «Journal of Research in Crime \& Delinquency» 1994, no. 31.

Brick J. M. and others, Cell phone survey feasibility in the U.S.: Sampling and calling cell numbers versus landline numbers, «Public Opinion Quarterly» 2007, no. 71.

Brick J. M. and others, Nonresponse bias in a dual frame sample of cell and landline numbers, «Public Opinion Quarterly» 2006, no. 70.

Costelloe M. T., Chiricos T., Gertz M., Exploring the relevance of crime salience and economic insecurity, «Punishment \& Society» 2009, no. 11.

Doran B., Burgess M., Putting Fear of Crime on the Map. Investigating Perceptions of Crime Using Geographic Information Systems, New York 2012.

Ferraro K. F., LaGrange R., The Measurement of Fear of Crime, «Sociological Inquiry» 1987, no. $57(1)$.

Franklin T., Franklin C., Fearn N., A multilevel analysis of the vulnerability, disorder, and social integration models of fear of crime, «Social Justice Research» 2008, no. 21.

Garofalo J., The Fear of Crime: Causes and Consequences, «Journal of Criminal Law and Criminology» 1981, no. 72 (2).

Gifi A., Nonlinear multivariate analysis, Wiley series in probability and mathematical statistics, Chichester 1990.

Greenacre M. J., Theory and Applications of Correspondence Analysis, London 1984.

Gruszczyńska B., Marczewski M., Siemaszko A., Atlas przestępczości w Polsce 4, Warszawa 2009.

Gruszczyńska B., Marczewski M., Siemaszko A., Atlas przestępczości w Polsce 5, Warsaw 2015.

33 A. Vieno, M. Roccato, S. Russo, Is fear of crime..., pp. 519-535; M. Visser, M. Scholte, P. Scheepers, Fear of crime..., pp. 278-301. 
Guttman L., A general nonmetric technique for finding the smallest coordinate space for a configuration of points, «Psychometrika»1968, no. 33 .

Hale C., Fear of Crime: A Review of the Literature, «International Review of Victimology» 1996, no. 4 (2).

Hale C., Pack P., Salked J., The structural determinants of fear of crime: an analysis using census and crime survey data from England and Wales, «International Review of Victimology» 1994, no. 3.

Hogan M. J., Chiricos T., Gertz M., Economic insecurity, blame, and punitive attitudes, «Justice Quarterly» 2005, no. 22.

Hołyst B., Wiktymologia, Warsaw 2011.

Jackson J., Bradford B., Hohl K., Farrall S., Does the Fear of Crime Erode Public Confidence in Policing?, «Policing» 2009, no. 3 (1).

Keeter S. and others, Costs and benefits of full dual frame telephone survey designs, Paper presented at the 63rd Annual Conference of the American Association for Public Opinion Research, New Orlean 2008.

Kennedy C., Evaluating the effects of screening for telephone service in dual frame RDD surveys, «Public Opinion Quarterly» 2007, no. 71.

King A., Maruna S., Is a conservative just a liberal who has been mugged? Exploring the origins of punitive views, «Punishment \& Society» 2009, no. 11.

Kruskal J. B., Multidimensional scaling by optimizing goodness of fit to a nonmetric hypothesis, «Psychometrika»1964, no. 29.

Lane J., Rader N. E., Henson B., Fisher B. S., May D. C., Fear of Crime in the United States: Causes, Consequences, and Contradictions, Durham 2014.

Lee H. D., Reyns B. W., Kim D., Fear of Crime Out West: Determinants of Fear of Property and Violent Crime in Five States, «International Journal of Offender Therapy and Comparative Criminology» 2020, no. 64 (12).

Macassa G., Winersjö R., Wijk K., McGrath C., Ahmadi N., Soares J., Fear of crime and its relationship to self-reported health and stress among men, "Journal of Public Health Research» 2017, no. 6 (3).

Meško G., Fallshore M., Rep M., Huisman A., Police Efforts in the Reduction of Fear of Crime in Local Communities - Big Expectations and Questionable Effects, «Sociologija. Mintis ir veiksmas» 2007, no. 2 (20).

Mider D., Ewaluacja wybranych metod badań społecznych w Internecie, [in:] D. Mider, A. Maksimowicz (eds.), Cyberpolitologia. Badanie polityki w Internecie, ACAD, Warsaw 2013.

Ostaszewski P., Lęk przed przestępczością. Aspekty teoretyczne, metodologiczne i empiryczne, Warsaw 2014.

Ostaszewski P., Nasilenie i determinanty lęku przed przestępczościa, Warsaw 2012.

Potthoff R. F., Some generalisation of the Mitofsky-Waksberg technique for Random Digit Dialing, «Journal of the American Statistical Association»1987, no. 82.

Rao Sekhara K. S., A Study on 'Impact of Investment Impeding Factors on Equity Rate of Return' in Power Projects, «Research Journal of Social Science \& Management» 2014, no. 4 (5).

Robinson B., Lawton B. A., Taylor R. B., Perkins D. D., Multilevel longitudinal impacts of incivilities: Fear of crime, expected safety, and block satisfaction, «Journal of Quantitative Criminology» 2003, no. 19.

Scarborough B., Like-Haislip T., Novak K., Lucas W., Alarid L., Assessing the relationship between individual characteristics, neighborhood context, and fear of crime, «Journal of Criminal Justice» 2010, no. 38.

Shepard R. N., The analysis of proximities: Multidimensional scaling with an unknown distance function. I, «Psychometrika»1962, no. 27. 
Shepard R. N., The analysis of proximities: Multidimensional scaling with an unknown distance function. II, «Psychometrika» 1962, no. 27.

Singer A. J., Chouhy C., Lehmann P. S., Wlazak J. N., Victimization, Fear of Crime, and Trust in Criminal Justice Institutions: A Cross-National Analysis, «Crime \& Deliquency» 2019, no. 65 (6).

Skogan W. G., Maxfield M. G., Coping with crime: individual and neighborhood reactions, Thousand Oaks 1981.

Skogan W. G., The impact of victimization on fear, «Crime Delinquency» 1987, no. 33.

Skogan W. G., The various meanings of fear, [in:] The Fear of Crime and Criminal Victimization, Stuttgart 1993.

Sundeen R. A., Mathieu J. T., The Fear of Crime and Its Consequences Among Elderly in Three Urban Communities, «The Gerontologist» 1976, no. 16 (3).

Szatan M., Strach a lęk w ujęciu nauk humanistycznych, «Studia Gdańskie» 2012, no. 31.

Tseloni A., Zarafonitou C., Fear of Crime and Victimisation: A Multivariate Multilevel Analysis of Competing Measurements, «European Journal of Criminology» 2008, no. 5.

Tucker C., Casady R., Lepkowski J., Sample Allocation For Stratified Telephone Sample Designs, Proceedings of the Survey Research Methods Sections, American Statistical Association, Alexandria 1992.

Vieno A., Roccato M., Russo S., Is fear of crime mainly social and economic insecurity in disguise? A multilevel multinational analysis, «Journal of Community \& Applied Social Psychology» 2013, no. 23.

Visser M., Scholte M., Scheepers P., Fear of crime and feelings of unsafety in European countries: Macro and micro explanations in cross-national perspectives, «The Sociological Quarterly» 2013, no. 54.

Waksberg J., Sampling Methods for Random Digit Dialing, «Journal of the American Statistical Association», 1978, no. 73.

Warr M., Fear of crime in the United States: Avenues for research and policy, «Criminal Justice» 2000, no. 4.

Wyant B., Multi-level impacts of perceived incivilities and perceptions of crime risk on fear of crime, «Journal of Research in Crime and Delinquency» 2008, no. 45. 